the interest must continue to rest on techniques of exploration and interpretation of evidence, and here there is no slackening of interest, for most of the Earth's surface is almost unexplored.

The facilities provided by the Food and Agriculture Organization and the Italian authorities were admirable. After several experiences of large meetings, one looks forward to those where headphones and simultaneous translations are provided. To be able always to hear is a wonderful asset, even if the language presents no difficulty. It is understood that the complete papers are to be published by Unesco and this will be worth while. A good proportion of the material had been heard or read before, but there would be no sense in insisting on complete novelty for an interdisciplinary meeting where the object is to exchange ideas, not to be mutually iricomprehensible.

R. C. SUTCLIFFE

\title{
CHEMICAL WARFARE ON PLANT PESTS AND DISEASES
}

T HE first British Insecticide and Fungicide Conference organized by the Association of British Manufacturers of Agricultural Chemicals was held at Brighton during November 7-9 under the presidency of Dr. H. G. Sanders, chief scientific adviser (agriculture) to the Ministry of Agriculture, Fisheries and Food. It was truly an international gathering, for of the 470 delegates attending from official research stations, Government departments and manufacturing firms, nearly one-quarter came from fourteen countries overseas.

The conference consisted of ten successive sessions devoted to important present-day problems in plant pathology and their possible solution by chemical means. During the first two days each session began with one or more introductory papers by authorities on the subject under discussion, and these were followed by brief reports of relevant research in progress at various centres. The morning of the third day was given over to research reports on now insecticides, fungicides and acaricides, and on novel formulations as well as new methods of application. In the final session attention was appropriately directed to the problems involved in translating research into practice and in introducing insecticides and fungicides into agricultural practice both in Britain and overseas. In all, more than fifty papers or reports were presented from the research departments of official agricultural institutes and industrial firms, including a number from Holland, Germany and Italy.

On introducing the president, Mr. H. C. Mellor, the chairman of the Manufacturers' Association and of the conference, said that the industry is at present under fire, though much of the criticism levelled at it is uninformed. The members of his Association are as anxious as anyone to find safer chemicals, and are most careful to honour the agreements made on their behalf with the Ministry of Agriculture, as well as to satisfy the requirements of the Notification Scheme under which all new chemicals are notified to the Ministry for clearance before marketing.

In his opening address Dr. Sanders referred to the increasingly important part played by chemicals in farming. Unfortunately, some of them are toxic to mammals and wild-life, and this has led to alarm in the public mind. He believed that much of this concern is due to ignorance of the many hurdles new chemicals have to surmount before they are cleared for marketing by Government departments of health and agriculture. The present conference was mainly a scientific one, but the delegates included meny whose functions were to translate science into practice, and it should therefore provide a good opportunity for getting things, including toxic hazards, into proper perspective. Dr. Sanders also commented on the close co-operation now existing between industry, research workers and Government officials, and expressed appreciation to the manufacturers for disclosing to him highly confidential information which has fully satisfied him that during the past five years there has been a very substantial reduction in the acreage sprayed with the more toxic chemicals, even though the total acreage sprayed has doubled during that period.

The first session was concerned with soil pests and diseases of agricultural crops, and included a review by Dr. Hubert Martin (until recently director of the Pesticide Research Institute, London, Ontario) of a symposium called privately, in February 1961, to discuss the effects of chlorinated hydrocarbons and other chemicals on the ecology of the soil fauna and flora. Dealing with the eelworm problem, $\mathbf{M r}$. F. G. W. Jones (Rothamsted Fxperimental Station) said that a first-class soil nematicide is still awaited. Only three-bromomethane, dibronioethane and dichloropropene-have stood the test of time, though some dithiocarbamates show promise. $\mathrm{He}$ doubted whether soil treatments were the right approach. Apart from difficulties of mixing and dispersion, at least 1,000 tons of soil per acre has to be treated. Eradication of eelworms is impossible and unnecessary, and he looked forward to a systemic nematicide moving from foliage to roots, suppressing the cyst-hatching factor, and perhaps passing out into the soil to exert a repellant effect. Dr. Mary Noble (Department of Agriculture for Scotland) considered that seed is not the best launching vehicle for a chemical intended to control soil-borne fungus diseases, while Mr. M. J. Way (Imperial College of Science and Technology) did much to restore a balance in the campaign against insecticidal seed dressings by insisting that the minute quantities used are effective and well placed and do not cause offflavours in crops, injure beneficial insects or encourage resistance in the pests attacked. The problem of deaths of birds after eating dressed seed should be met by more circumspect use of seed dressings and not by restrictive legislation, a view that received much support.

The use of systemic insecticides for virus control in potatoes and sugar beet was considered at a second session. Hitherto, potato virus diseases have been controlled through crop certification schemes, a method that has become traditional. Dr. L. Broadbent (Glasshouse Crops Research Institute) and others have shown that similar ends may be achieved by using systemic insecticides, though fow farmers have yet attempted to take advantage of this. With sugar beet thore has been no tradition of certification. and farmers responded quickly to a spray-warning scheme begun in 1957 to deal with virus yellows. Dr. R. Hull 
(Rothamsted Experimental Station) disclosed that 95 per cent of the crop was sprayed in 1959 and suggested that spraying had converted 1961 from a 'severe' to a 'marginal' yellows year. Other reports about this diserse dealt with the value of menazon and dimethoate as sprays, and with the application of granular formulations of phorate and thiodemeton to the soil or foliage.

In a session on forecasting pest and disease outbreaks great interest was shown in the pioneering work of Mr. G. H. Brenchley (Ministry of Agriculture, Fisheries and Food) on the use of aerial infra-red photography to detect the primary foci of potato blight and to study patterns of its early natural spread. Dr. E. Evans (Fisons Pest Control, Ltd.) reported on difficulties in evaluating materials for blight control and suggested that the performance of copper products and dithiocarbamates differs accord. ing to the nature of the epidemic.

Three sittings were devoted respectively to apple mildew, fruit tree pests and the control of Botrytis diseases. It was obvious some years ago that apple mildew would again become the problem it now is, and older delegates listening to the seven speakers no doubt recalled similar discussions held thirty years and more ago. In the meantime, mildew has been adequately controlled under a sulphur programme for apples, but it became resurgent as captan and organo-mercury sprays replaced sulphur for scab control and as the renewal system of pruning evolved. Much of the discussion revolved around the difficulty of dealing with continuous conidial inoculum and preventing bud infection, which can evidently be fully accomplished only by weekly or even more frequent application of dinocap or other appropriate fungicides. On fruit tree pests, Dr. G. H. Dicker (East Malling Research Station) and others emphasized the importance of a knowledge of the biology of red spider mite, codling moth and tortrix in the effective timing of fruit tree sprays during the flowering period. No specific methods emerged for dealing with species of Botrytis, notably $B$. cinerea, which causes so much destruction to many crops, and the prospect was not made brighter by the ease with which Dr. R. K. S. Wood (Imperial College of Science and Technology) has been able to produce in vitro strains of Botrytis highly resistant to the fairly effective chlorinated nitrobenzenes. To protect strawberry and raspberry fruits, Dr. W. R. Jarvis (Scottish Horticultural Research Institute) felt that the only real solution would be in a systemic fungicide applied before the flowering stage.

In a session on soil sterilants, Dr. W. Madel (CELA, G.m.b.H.) described experience in Germany with metham-sodium against harmful soil organisms, and Dr. L. P. Flipse (Ligtermoet and Zoon N.V.) showed how valuable this fumigant and herbicide is to Dutch horticulture, porticularly in controlling soil-borne fungus diseases of bulbs, carnations and tomatoes. But though practical results continue to accumulate, little is yet known about the mode of action of soil sterilants.

Comment on much of the work discussed at the conference must perforce await publication in the Proceedings. Other items included progress reports on a number of new aphicides and acaricides, on the potentialities of organic tin compounds and polybutene formulations, and on special formulations for low-volume spraying. In all the developments out. lined it was not difficult to perceive a general desire to find effective chemicals of low mammalian toxicity (if possible, systemic in action) having prolonged effects, and preferably applied in a form that reduces hazards to man, animal and wild-life to the absolute minimum. It was also encouraging to loarn from the Laboratory of the Government Chemist of the progress being made in solving the problems which face the analyst examining foodstuffs for pesticide residues.

Speaking as an adviser concerned with the translation of research into practice in Great Britain, Dr. M. Cohen (Ministry of Agriculture, Fisheries and Food) emphasized the difficulty that faces everyone confronted with the vast number of new materials produced during the past fifteen years, and referred to the apparently insoluble problem posed by the confusing combination of endless chemical, common and proprietary names for insecticides and fungicides on the market. Finally, and in an absorbing talk that was delightfully refreshing at the end of three days of "sharing the benefits of new knowledge", Mr. G. Ordish (Department of Technical Co-operation, Tropical Products Institute) dealt with the introduction of insecticides and fungicides into agricultural practice overseas. Little had been said at the conference about economics, though in his view this was perhaps the most important factor of all. In his closing remarks the president mentioned some of the highlights of the discussions and expressed the hope that the conference would be but the first of a biennial series.

\section{THE SOVIET HYDROMETEOROLOGICAL SERVICE}

DECREE, signed by Lenin in June 1921, was
Hydrometeorological Service. In a recent issue of
Meteorologija $i$ Gidrologija (No. 6, 1961) the present
chief director, A. A. Zolotuhin, traces the history of
the Service over the ensuing forty years.
There had been a small meteorological service in
Tmperial Russia, but owing to foreign and civil war
it was in a state of complete decline by 1921 . Pro-
gress, however, was slow and inadequate during the
'twenties, and by 1929 there were twelve meteoro-
logical services in the U.S.S.R. which arose from
departments forming their own services, because the
main service could not meet their demands. The
U.S.S.R. has for long undoubtedly regarded soundly administered and technically efficient hydrometeorological service as essential to its national economy and to its defence. So in the early 'thirties a unified service was recreated and thereafter progress was rapid. For example, it is claimed that the world's first radiosonde was released in January 1930, and that a network of sounding stations was immediately commenced. By 1941, at the outbreak of War, forty radiosonde stations were in being. Advances in other directions were also substantial.

This was, of course, a period of great expansion for many national meteorological services owing to the development of the science itself and to the increasing demands of military and civil aviation. The U.S.S.R. was clearly no exception. 